\title{
PENGARUH KUALITAS PRODUK DAN KUALITAS PELAYANAN TERHADAP KEPUASAN PELANGGAN RUMAH MAKAN MM RESTO KARAWANG
}

\author{
Dedi Mulyadi \\ Universitas Buana Perjuangan Karawang \\ Email: dedi.mulyadi@ubpkarawang.ac.id
}

\begin{abstract}
Abstrak
Tujuan penelitian ini adalah untuk mengetahui dan menganalisa pengaruh kualitas produk dan pelayanan terhadap kepuasan pelanggan Rumah Makan MM Reso Karawang baik seacara parsial maupun secara simultan. Penelitian ini menggunakan metode kuantitatif yang bersifat verifikatif. Hasil penelitian membuktikan bahwa secara simultan, kualitas produk dan pelayanan berpengaruh positif terhadap kepuasan pelanggan. Sedangkan secara pasrial, variabel kualitas produk dan kualitas pelayanan berpengaruh terhadap kepuasan pelanggan. Secara parsial, kualitas produk memberikan pengaruh lebih besar terhadap kepuasan pelanggan daripada kualitas pelayanan.
\end{abstract}

Kata Kunci: Kualitas Produk, Kualitas Pelayanan, Kepuasan Pelanggan.

\begin{abstract}
The purpose of this study was to determine and analyze the effect of product and service quality on customer satisfaction at MM Reso Karawang Restaurant either partially or simultaneously. This research uses quantitative methods that are verification. The research proves that simultaneously, product quality and service have a positive effect on customer satisfaction. While pasrial, product quality and service quality variables affect customer satisfaction. Partially, product quality has a greater influence on customer satisfaction than service quality.
\end{abstract}

Keywords: Product Quality, Service Quality, Customer Satisfaction.

\section{A. PENDAHULUAN}

Perkembangan industri kuliner saat ini sangat pesat mulai dari negara-negara maju dan berkembangpun mengikuti perkembangan bisnis industri kuliner ini, begitu juga di indonesia pola konsumsi masyarakat akan makanan telah mengalami pergeseran dimana masyarakat lebih senang untuk mengkonsumsi makanan diluar rumah terutama bagi masyarakat yang sibuk bekerja dan beraktifitas diluar rumah, industri kuliner inipun terjadi pada kota karawang, hal ini terjadi karena adanya faktor-faktor yang mendukung perkembangan bisnis tersebut, MM Resto adalah salah satu restoran yang berdiri di tengah menjamurnya bisnis restoran di kota karawang, MM resto merupakan restoran dengan konsep yang sederhana yang menyajikan menu makanan dengan resep sendiri dan menawarkan 
suasana yang nyaman dengan fasilitas adanya musik organ yang di siapkan oleh pengelola rumah makan, yang menjadi ciri khas rumah makan ini.

Dalam rangka menciptakan kepuasan konsumen, perusahaan perlu melakukan usaha pembinaan terhadap langganan, untuk itu perlu adanya tindakan strategi pemasaran yang tepat sesuai dengan prilaku konsumen tersebut, kualitas produk merupakan hal yang perlu mendapatkan perhatian utama, karena kualitas produk akan berhubungan langsung dengan kemampuan restoran untuk bersaing dan volume keuntungan yang akan di peroleh. Kepuasan konsumen juga sangat di tentukan pula oleh baik tidaknya sebuah layanan yang di berikan perusahaan dalam memasarkan produknya.

\section{B. TINJAUAN PUSTAKA}

\section{Kualitas Produk}

Kotler dan Amstrong (2008:272), menjelaskan bahwa Kualitas produk adalah karakteristik produk atau jasa yang tergantung pada kemempuannya untuk memuaskan kebutuhan pelanggan yang dinyatakan atau di implikasikan.

Sedangkan Menurut Feignbaum dalam nasution (2001:16), mengatakan bahwa suatu produk dapat di katakan berkualitas jika produk tersebut dapat memberikan kepuasan terhadap konsumen, produk tersebut sesuai dengan apa yang diharapkan.

Menurut Fandi Tjiptono dan Gregorius Chandra (2012:75) mengemukakan kualitas memiliki beberapa dimensi pokok, dalam kasus pemasaran produk ada delapan dimensi utama yang biasanya digunakan:

a. Kinerja (performance): karaketristik operasi dasar dari suatu produk, misalnya kecepatan pengiriman paket titipan kilat, ketajaman gambar dan warna sebuah TV, serta kebersihan masakan di restoran.

b. Fitur (features): karakteristik pelengkap khusus yang bisa menambah pengalaman pemakaian produk, contohnya minuman gratis selama penerbangan pesawat, AC mobil, dan koleksi tambahan aneka nada panggil pada telepon genggam.

c. Reliabilitas, yaitu probabilitas terjadinya kegagalan atau kerusakan produk dalam periode waktu tertentu. Semakin kecil kemungkinan terjadinya kerusakan, semakin andal produk bersangkutan.

d. Konformasi (conformance), yaitu tingkat kesesuaian produk dengan standar yang telah di tetapkan, misalnya ketepatan waktu keberangkatan dan kedatangan kereta api. 
e. Daya tahan (durability), yaitu jumlah pemakaian produk sebelum produk bersangkutan harus diganti. Semakin besar frekuensi pemakaian normal yang dimungkinkan, semakin besar pula daya tahan produk.

f. Serviceability, yaitu kecepatan dan kemudahan untuk direparasi, serta kompetensi dan keramahtamahan staf layanan.

g. Estetika (aestetics), menyangkut penampilan produk yang bisa dinilai dengan panca indra (rasa, aroma, suara, dan seterusnya).

h. Persepsi terhadap kualitas (perceived quality), yaitu kualitas yang dinilai berdasarkan reputasi penjual.

\section{Kualitas Pelayanan}

Menurut Wyckof (dalam Fandi Tjiptono, 2004:59), Kualitas pelayanan adalah tingkat keunggulan yang diharapkan dan pengendalian atas tingkat keunggulan tersebut untuk memenuhi keinginan pelanggan. Dengan kata lain, ada dua faktor yang mempengaruhi kualitas jasa, yaitu expected service dan perceived service.

Menurut kotler dalam buku Manajemen Pemasaran dan Pemasaran Jasa (Buchari Alma,2013:284) mengungkapkan ada lima faktor dominan atau penentu kualitas jasa disingkat dengan TERRA yaitu:

a. Tangible (berwujud), yaitu berupa penampilan fasilitas fisik, peralatan dan berbagai materi komunikasi yang baik, menarik, terawat, lancar dsb.

b. Empathy, yaitu kesediaan karyawan dan pengusaha untuk lebih peduli memberikan perhatian secara pribadi kepada langganan.

c. Responsiviness (cepat tanggap), yaitu kemauan dari karyawan dan pengusaha untuk membantu pelanggan dan memberiakan jasa dengan cepat serta mendengar dan mengatasi keluhan/complain dari konsumen.

d. Reliability (keandalan), yaitu kemempuan untuk memberikan layanan/jasa sesuai dengan yang dijanjikan, terpercaya dan akurat, dan konsisten.

e. Assurance (kepastian), yaitu berupa kemampuan karyawan untuk menimbulkan keyakinan dan kepercayaan terhadap janji yang telah dikemukakan kepada konsumen.

\section{Kepuasan Pelanggan}

Zulian Yamit (2013:78), mengatakan bahwa kepuasan pelanggan adalah konsumen yang melakukan pembelian ulang atas produk dan jasa yang dihasilkan perusahaan. 
Menurut Zeithaml \& Bitner dalam (Basrah Saidani, 2012:6) Kepuasan pelanggan adalah respon pelanggan terhadap evaluasi ketidaksesuaian yang dirasakan antara harapan dan kinerja aktual jasa.

Dalam mengevaluasi kepuasan terhadap produk, jasa atau perusahaan tertentu konsumen umumnya mengacu pada beberapa faktor atau dimensi. Faktor yang sering digunakan dalam mengevaluasi kepuasan terhadap suatu produk manufaktur (Garvin dala 2008:25) antara lain meliputi:

a. Kinerja (performance) Karakteristik operasi pokok dari produk inti (Core Product) yang dibeli.

b. Ciri-ciri atau keistimewaan tambahan (Features), yaitu karakteristik sekunder atau pelengkap, misalkan kelengkapan interior dan eksterior.

c. Keandalan (Reliability) yaitu kemungkinan kecil akan mengalami kerusakan atau gagal pakai.

d. Kesesuaian dengan spesifikasi yaitu sejauhmana karakteristik desain dan operasi memenuhi standar yang ditentukan sebelumnya.

e. Daya tahan (Durability) berkaitan dengan berapa lama produk tersebut dapat bisa digunakan. Dimensi ini mencaqngkup umur teknismaupun umur ekonomis

f. Serviceability, meliputi kecepatan, kompetensi kenyamanan mudah direvarasi serta penanganan keluhan yang memuaskan.

g. Estetika yaitu daya tarik produk terhadap panca indra.

h. Kualitas yang dipersepsikan (Perceived Quality) yaitu citra dan reputasi produk serta tanggung jawab perusahaan terhadapnya. Biasanya karena kurangnya pengetahuan pembelian atas atribut ciri-ciri produk yang akan dibeli, makan pembeli mempersiapkan kualitas dari aspek harga, nama merek, iklan reputasi perusahaan.

\section{METODE PENELITIAN}

Penelitian ini dilakukan dengan menggunakan metode survey. Menurut Sugiyono (2012:6) bahwa metode survey digunakan untuk mendapatkan data dari tempat tertentu yang alamiah (bukan buatan), tetapi peneliti melakukan perlakuan dalam mengumpulkan data, misalnya dengan mengedarkan kuisioner, test, wawancara terstruktur dan sebagainya Penelitian ini termasuk kedalam penelitian assosiatif yang bertujuan untuk mengetahui hubungan antara dua variabel atau lebih. Dimana hubungan antara variabel dalam penelitian 
akan dianalisis dengan menggunakan ukuran-ukuran statistika yang relevan atas data tersebut untuk menguji hipotesis (Sugiyono, 2008:5).

Populasi dari penelitian ini adalah konsumen Rumah makan MM Resto Karawang dengan estimasi banyaknya jumlah pelanggan pada bulan april 2015 sekitar 530 pelanggan. Dalam penelitian ini konsumen yang dipilih adalah konsumen yang berkunjung dan pernah berkunjung ke Rumah Makan MM Resto. Pengumpulan data dilakukan dengan penyebaran kuesioner kepada para responden. Setelah data terkumpul maka dilakukan analisis data dengan analisis statistik.

\section{HASIL DAN PEMBAHASAN}

\section{Rekapitulasi Kuisioner Kualitas Produk}

Berikut ini disajikan hasil rekapitulasi kuesioner variabel kualitas produk pada RM MM Resto Karawang:

Tabel 1

Rekapitulasi Kuisioner Kualitas Produk

\begin{tabular}{|c|l|c|c|}
\hline No & \multicolumn{1}{|c|}{ Indikator Kualitas Produk } & Skor & Keterangan \\
\hline 1 & Rasa makanan & $\mathbf{5 9 1}$ & Tidak baik \\
\hline 2 & Kebersihan makanan & $\mathbf{5 1 1}$ & Tidak baik \\
\hline 3 & Variasi menu & $\mathbf{5 8 5}$ & Tidak baik \\
\hline 4 & Rasa minuman & $\mathbf{6 0 2}$ & Cukup Baik \\
\hline 5 & Standarisasi makanan dan minuman & $\mathbf{5 2 0}$ & Tidak baik \\
\hline 6 & Daya tahan makanan & $\mathbf{6 4 1}$ & Cukup baik \\
\hline 7 & Kecepatan penyajian & $\mathbf{6 0 7}$ & Cukup baik \\
\hline 8 & Tampilan makanan & $\mathbf{5 9 7}$ & Tidak baik \\
\hline 9 & Kenyamanan rumah makan & $\mathbf{6 0 6}$ & Cukup baik \\
\hline 10 & Kesegaran makanan & $\mathbf{6 6 6}$ & Cukup baik \\
\hline 11 & Reputasi rumah makan & $\mathbf{5 5 8}$ & Tidak baik \\
\hline 12 & Konsep rumah makan & $\mathbf{5 7 6}$ & Tidak baik \\
\hline & Modus Jawaban Responden & $\mathbf{5 8 8}$ & Tidak baik \\
\hline
\end{tabular}

Berdasarkan tabel 1 di atas, diketahui bahwa kualitas produk RM MM Resto Karawang terdapat pada kriteria tidak baik dengan nilai yang sering muncul berada pada rentang skala 410-593, Sehingga dapat disimpulkan secara umum bahwa responden (konsumen) menilai tidak baik terhadap pernyataan yang diungkap dalam kuisoner mengenai Kualitas Produk RM MM Resto Karawang.

\section{Rekapitulasi Kuisioner Kualitas Pelayanan}

Berikut ini disajikan hasil rekapitulasi kuesioner variabel kualitas pelayanan pada RM MM Resto Karawang: 
Tabel 2

Rekapitulasi Kuisioner Kualitas Pelayanan

\begin{tabular}{|c|c|c|c|}
\hline No & Indikator Kualitas Pelayanan & Skor & Keterangan \\
\hline 1 & Fasilitas peralatan & 623 & Cukup Baik \\
\hline 2 & Kebersihan dan kerapihan karyawan & 610 & Cukup Baik \\
\hline 3 & Cepat tanggap karyawan & 610 & Cukup Baik \\
\hline 4 & Ketepatan dalam Bertransaksi & 611 & Cukup Baik \\
\hline 5 & Area parkir & 543 & Tidak Baik \\
\hline 6 & Sarana tempat ibadah & 653 & Cukup Baik \\
\hline 7 & Kebersihan toilet & 622 & Cukup Baik \\
\hline 8 & Kemampuan karyawan & 589 & Tidak Baik \\
\hline 9 & Standarisasi pelayanan & 609 & Cukup Baik \\
\hline 10 & Keramahan Karyawan & 687 & Cukup Baik \\
\hline 11 & Penanganan keluhan & 580 & Tidak Baik \\
\hline 12 & Tanggung jawab karyawan dalam berprilaku & 606 & Cukup Baik \\
\hline & Modus Jawaban Responden & 611 & Cukup Baik \\
\hline
\end{tabular}

Berdasarkan tabel 2 di atas, diketahui bahwa kualitas pelayanan RM MM Resto Karawang terdapat pada kriteria cukup baik dengan nilai yang sering muncul berada pada rentang skala 594-776, Sehingga dapat disimpulkan secara umum bahwa responden (konsumen) menilai cukup baik terhadap pernyataan yang diungkap dalam kuisoner mengenai Kualitas Pelayanan RM MM Resto Karawang.

\section{Rekapitulasi Kuisioner Kepuasan Pelanggan}

Berikut ini disajikan hasil rekapitulasi kuesioner variabel kepuasan pelanggan pada RM MM Resto Karawang:

Tabel 3

Rekapitulasi Kuisioner Kepuasan Pelanggan

\begin{tabular}{|c|l|c|c|}
\hline No & \multicolumn{1}{|c|}{ Indikator Kepuasan Pelanggan } & Skor & Keterangan \\
\hline 1 & Kebersihan rumah makan & $\mathbf{5 9 4}$ & Tidak Puas \\
\hline 2 & Kenyamanan rumah makan & $\mathbf{5 1 3}$ & Tidak Puas \\
\hline 3 & Menu makanan & $\mathbf{5 9 0}$ & Tidak Puas \\
\hline 4 & Konsep rumah makan & $\mathbf{5 9 2}$ & Tidak Puas \\
\hline 5 & Fasilitas rumah makan & $\mathbf{6 0 5}$ & Tidak Puas \\
\hline 6 & Keamanan rumah makan & $\mathbf{6 4 2}$ & Cukup Puas \\
\hline 7 & Empati dari karyawan & $\mathbf{5 4 2}$ & Cukup Puas \\
\hline 8 & Informasi yang diberikan karyawan & $\mathbf{5 8 9}$ & Tidak Puas \\
\hline 9 & Hubungan baik karyawan & $\mathbf{5 9 0}$ & Tidak Puas \\
\hline 10 & Penanganan keluhan & $\mathbf{6 0 9}$ & Cukup Puas \\
\hline
\end{tabular}




\begin{tabular}{|c|l|c|c|}
\hline 11 & Kemudahan menghubungi karyawan & $\mathbf{5 8 0}$ & Tidak Puas \\
\hline 12 & Keramahan karyawan & $\mathbf{6 0 9}$ & Cukup Puas \\
\cline { 2 - 4 } & Modus Jawaban Responden & $\mathbf{5 8 7}$ & Tidak Puas \\
\hline
\end{tabular}

Berdasarkan tabel 3 di atas, diketahui bahwa kepuasan pelanggan RM MM Resto Karawang terdapat pada kriteria puas dengan nilai yang sering muncul berada pada rentang skala 410-593, Sehingga dapat disimpulkan secara umum bahwa responden (konsumen) menilai tidak puas terhadap pernyataan yang diungkap dalam kuisoner mengenai Kepuasan Pelanggan RM MM Resto Karawang.

\section{Korelasi antara Variabel Bebas}

Berikut ini disajikan hasil korelasi antara variabel kualitas produk dengan kualitas pelayanan pada RM MM Resto Karawang:

Tabel 4

Korelasi Antara Kualitas Produk (X1) dengan Kualitas Pelayanan (X2)

\begin{tabular}{|ll|r|r|}
\hline & $\begin{array}{c}\text { Kualitas } \\
\text { Produk }\end{array}$ & $\begin{array}{c}\text { Kualitas } \\
\text { Pelayanan }\end{array}$ \\
\hline $\begin{array}{l}\text { Kualitas_ } \\
\text { Produk }\end{array}$ & 1 & .822 \\
& Searson Correlation & & .215 \\
$\mathrm{~N}$ & 228 & 228 \\
\hline Kualitas_tailed) & Pearson Correlation & .822 & 1 \\
Ploduk & Sig. (2-tailed) & .215 & \\
& $\mathrm{~N}$ & 228 & 228 \\
\hline
\end{tabular}

Korelasi diantara variabel bebas yaitu Kualitas Produk dan Kualitas Pelayanan menunjukkan korelasi sebesar 0,822, hal ini menunjukkan terdapat korelasi positif antara Kualitas Produk dan Kualitas Pelayanan. Hal ini menunjukkan bahwa Kualitas Produk dapat menciptakan Kualitas Pelayanan.

\section{Analisis Jalur}

Berikut ini disajikan hasil hasil analisis jalur pada setiap variabel: 


\section{Tabel 5}

Koefisien Jalur

\begin{tabular}{|c|c|c|c|c|c|c|}
\hline & & \multicolumn{2}{|c|}{$\begin{array}{l}\text { Unstandardized } \\
\text { Coefficients }\end{array}$} & $\begin{array}{l}\text { Standardized } \\
\text { Coefficients }\end{array}$ & \multirow[b]{2}{*}{$\mathrm{t}$} & \multirow[b]{2}{*}{ Sig. } \\
\hline \multicolumn{2}{|c|}{ Model } & B & Std. Error & Beta & & \\
\hline & (Constant) & 31.460 & 2.957 & & 10.639 & .000 \\
\hline & $\begin{array}{l}\text { Kualitas_ } \\
\text { Produk }\end{array}$ & -.051 & .068 & -.515 & -.757 & .450 \\
\hline & $\begin{array}{l}\text { Kualitas_ } \\
\text { Pelayanan }\end{array}$ & .033 & .059 & .388 & .567 & .571 \\
\hline
\end{tabular}

Berdasarkan tabel di atas diketahui bahwa erdapat pengaruh parsial dari Kualitas Produk terhadap Kepuasan Pelanggan RM MM Resto Karawang dengan koefisien jalur sebesar 0,269 atau 26,9\%. Hal ini menunjukkan bahwa Kualitas Produk berkontribusi atau memiliki pengaruh terhadap Kepuasan Pelanggan RM MM Resto Karawang. Terdapat pengaruh parsial dari Kualitas Pelayanan terhadap Kepuasan Pelanggan RM MM Resto Karawang dengan koefisien jalur sebesar 0,154 atau 15,4\%. Hal ini menunjukkan bahwa Kualitas Pelayanan berkontribusi atau memiliki pengaruh terhadap Kepuasan Pelanggan RM MM Resto Karawang.

Terdapat pengaruh simultan dari Kualitas Produk dan Kualitas Pelayanan terhadap Kepuasan Pelanggan RM MM Resto Karawang dengan koefisien determinasi sebesar 0,423 atau $42,3 \%$ sedangkan 0,577 atau $57,7 \%$ dipengaruhi oleh faktor lain yang tidak diteliti dalam penelitian ini. Hal ini menunjukkan bahwa Kualitas Produk dan Kualitas Pelayanan secara bersama-sama memiliki pengaruh terhadap Kepuasan Pelanggan RM MM Resto Karawang.

\section{Analisis Koefisien Determinasi}

Adapun nilai koefisien determinasi/Coefficient Determined (CD) terhadap korelasi antara variabel Kualitas Produk terhadap Kepuasan Pelanggan dapat dijelaskan sebagai berikut:
$\mathrm{CD}=r^{2} \times 100 \%$
$\mathrm{CD}=(0,515)^{2} \times 100 \%$
$\mathrm{CD}=0,2652 \times 100 \%$
$\mathrm{CD}=26,52 \%$ 
Adapun nilai koefisien determinasi/Coefficient Determined (CD) terhadap korelasi antara variabel Kualitas Pelayanan terhadap Kepuasan Pelanggan dapat dijelaskan sebagai berikut:

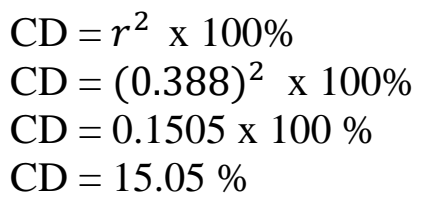

\section{E. KESIMPULAN}

Hasil penelitian membuktikan bahwa secara simultan, kualitas produk dan pelayanan berpengaruh positif terhadap kepuasan pelanggan pada RM MM Resto Karawang. Sedangkan secara pasrial, variabel kualitas produk dan kualitas pelayanan berpengaruh terhadap kepuasan pelanggan pada pada RM MM Resto Karawang. Secara parsial, kualitas produk memberikan pengaruh lebih besar terhadap kepuasan pelanggan daripada kualitas pelayanan.

\section{DAFTAR PUSTAKA}

Alma, B. (2013). Manajemen Pemasaran dan Pemasaran Jasa. Bandung: Alfabeta.

Assauri, S. (2014). Manajemen Pemasaran. Jakarta: Rajawali Pers.

Basrah, S. (2012). Pengaruh Kualitas Layanan Terhadap Kepuasan Konsumen dan Minat Beli pada Ranch Market. Jurnal Riset Manajemen Sains Indonesia (JRMSI), 3(1).

Darmawan, H. (2014). Pengaruh Bauran Pemasaran Terhadap Kepuasan Konsumen pada Kafe Kopi Tiam Lima Waktu Karawang. Skipsi Unsika.

Hasibuan, M. S. P. (2009). Manajemen Sumberdaya Manusia. Jakarta: Bumi Aksara.

Hoerunisa, Y. (2014). Pengaruh Bauran Promosi dan Diversivikasi Produk Terhadap Kepuasan Pelanggan (Study Kasus Pada Klinik Kecantikan Wijaya Skin Care Karawang). Skripsi Unsika.

Juliansyah, N. (2011). Metode Penelitian: Skipsi, Tesis, Disertai, dan Karya Ilmiah. Jakarta: Kencana Predana Media Group.

Kotler, P., \& Amstrong, G. (2008). Prinsip-prinsip Pemasaran. Jakarta: Indeks.

Kotler, P., \& Amstrong, G. (2007). Manajemen Pemasaran. Jakarta: Erlangga.

Laksana, F. (2008). Manajemen Pemasaran Pendekatan Praktis. Yogyakarta: Graha Ilmu.

Nasution. (2001). Manajemen Mutu Terpadu. Jakarta: Ghalia Indonesia.

Prahastuti, L. (2012). Analisis Pengaruh Kualitas Layanan dan Kualitas Produk Terhadap Kepuasan Konsumen Untuk Meningkatkan Loyalitas Konsumen Indosat. Skripsi Universitas Diponegoro.

Rangkuti, F. (2002). Riset Pemasaran. Jakarta: Gramedia Pustaka Utama. 
Riduwan \& Kuncoro, A. (2012). Cara Menggunakan dan Memakai Path Analisis. Bandung: Alfabeta.

Sugiyono. (2014). Metode Penelitian Kuantitatif Kualitatif dan R\&D. Bandung: Alfabeta.

Tjiptono, F., \& Chandra, G. (2012). Pemasaran Strategik. Yogyakarta: Andi.

Tjipton, Fandi, 2004, Strategi Pemasaran, Bandung: Linda Karya.

Yamit, Z. (2013). Manajemen Kualitas Produk dan Jasa. Yogyakarta: Ekonisia. 